\title{
ASPEK KEAGAMAAN DALAM KEHIDUPAN SOSIAL MASYARAKAT TORAJA DI DESA SARIRA, RANTEPAO, TANATORAJA
}

\begin{abstract}
H. Abubakar Surur
ABSTRAK

Kecenderungan pola hidup modern tidak cukup kuat mempengaruhi keunikan budaya Toraja. Dan keunikan tersebut tetap mampu mempertahankan eksistensi terutama karena kuatnya unsur kepercayaan lama. Sejauhmana aspek kepercayaan berpengamh dalam kehiduan masyarakat itulah yang menjadi masalah peneltian dalam studi ini. Dengan menggunakan pendekatan kualitatif ditemukan bahwa walaupun secara formal masyarakat Sarira, salah satu desa yang dijadikan studi kasus, telah menganut agama Kristen dan Islam, namun kepercayuaan baru tersebut tidak membuat mereka melepaskan diri dari ikatan kepercayaan nenek moyang yang disebut Aluk Todolo. Ada dua upacara yang sangat dominan dari tradisi Aluk Todolo daiam kehidupan masyarakat setempat yaitu Rambu Tuka dan Rambu Solo, yang pertama merupakan keberuntungan sedang yang kedua berkaitan dengan duka.
\end{abstract}

\section{PENDAHULUAN}

\section{A. Latar Belakang dan Masalah}

Nilai-nilai keagamaan yang hidup dalam sistem sosial masyarakat dan kesadaran akan nilai-nilai ketuhanan, menunjukkan bahwa Indonesia adalah bangsa yang religius. Di samping itu, pengungkapan nilai-nilai keagamaan yang berwujud dalam bentuk praktek dan tindakan, tidak terlepas dari budaya bangsa Indonesia sebagai warisan leluhur, yang masih dipertahankan secara tradisional dalam kehidupan sosial masyarakat.

Ekspresi keagamaan masyarakat Indonesia bervariasi, mengingat bangsa Indonesia terdiri dari berbagai suku yang memiliki simbol, terdiri dari tingkah laku yang berbeda, walaupun mereka samasama penganut agama dan kepercayaan terhadap Tuhan Yang Maha Esa.

Secara kenyataan bahwa agama dalam kehidupan sosial saling pengaruh mempengaruhi. Agama mempengaruhi jalannya kehidupan masyarakat, demikian pula sebaliknya, pertumbuhan masyarakat mempengaruhi pikiran terhadap agama (Mukti Ali, 1982 : 32).

Masyarakat Toraja memiliki pola interaksi sosial warisan budaya turun temurun yang mewujud dalam bentuk "tongkonan" dan "saroan". Tongkonan merupakan lembaga sosial kekerabatan, sedang soroan merupakan lembaga sosial territorial (Sy. Moh. Fuad, 1985: 2). Kedua lembaga tersebut merupakan penjabaran dari kepercayaan dan ketaatan masyarakat Toraja terhadap ajaran dan peran-peran leluhur mereka yag disebut "Aluk Todolo"

Upacara-upacara tradisional yang mirip dengan ritual keagamaan masih didominasi oleh Aluk Todolo, walau mereka telah manganut salah satu agama seperti Kristen Katholik atau Islam. Kedudukan Aluk Todolo di tengah-tengah masyarakat Toraja, termasuk mereka yang telah menganut agama, merupakan jaringan kerukunan umat beragama, karena keberadaan Aluk Todolo sebagai budaya, sangat dominan dan strategis bagi masyarakat Toraja. 
Untuk mengungkap aspek-aspek keagamaan yang berpengaruh dalam kehidupan sosial masyarakat Toraja yang masih sangat ketat memelihara budaya yang diwariskan leluhur mereka, maka penelitian ini dilakukan dengan fokus masalah :

- Sejauhmana aspek keagamaan berpengaruh dalam kehidupan sosial masyarakat.

- Dalam bentuk bagaimana keagamaan itu berpengaruh dalam masyarakat.

\section{B. Tujuan dan Kegunaan Penelitian}

Penelitian ini bertujuan untuk mengungkapkan aspek-aspek keagamaan yang hidup dalam sistem sosial Suku Toraja, terutama yarg berwujud dalam bentuk praktek dan tindakan.

Hasil penelitian diharapkan dapat berguna bagi penunjang kebijaksanaaan dalam rangka bimbingan dan pelayanan kehidupan keagamaan di samping dapat pula menjadi input dan bahan stud! bagi lembaga-lembaga penelitian. danorganisasi sosial keagamaan.

\section{Operasionalisasi Konsep}

Penelitian ini mempelajari cara ketakwaan orang Toraja terhadap Ketuhanan Yang Maha Esa, yang muncul dalam bentuk praktek atau tindakan mereka sehari-hari yang mencerminkan kehidupan beragama dan kehidupan sosial mereka. Agama dalam bentuk konteks ini adalah seperrngkat peugetahuan, kepercayaan, peribadatan, tindakan dan peng amalan keagamaan yang berkenaan dengan yang gaib.

Pengertian agama yang dijadikan acuan dalam penelitian ini adalah : Setiap agama merupakan suatu sistem yang terdiri atas empat komponen, masingmasing : emosi keagamaan, sistem keyakinan, sistem ritus dan upacara, umat atau kesatuan sosial keagamaan (Koen tjaraningra, $1985: 144)$.
Masyarakat adalah suatu kehidupan sosial manusia yang menempati suatu wilayah tertentu yang keteraturan dan kehidupan sosial tersebut telah dimungkinkan karena adanya pranata-pranata sosial yang telah menjadi tradisi dan kebudayaan yang dimiliki bersama (Suparlan; 1988 : 83). Agama dan kepercayaan yang dijadikan sebagai sistem keyakinan yang dimiliki secara individual yang diwujudkan dalam tingkah laku dan perbuatan dalam bentuk upacara atau ibadah yang sifatnya perorangan atau kelompok sehingga merupakan kesatuan hidup yang berinteraksi menurut sistem adat istiadat tertentu dan terikat oleh suatu rasa identitas bersama.

\section{LOKASI PENELITIAN}

Penelitian ini dilakukan di Desa Sarira, Kecamatan Rantepao, Kabupaten Tana Toraja. Keadaan alamnya datar dan merupakan daerah pertanian. Dari 10,31 Km luas desa, 12.225 ha adalah persawahan yang menghasilkan padi sekali setahun dengan tadah hujan. Selain padi, sawah menghasilkan jagung. Kebun seluas 215 ha menghasilkan kopi dan coklat. Ketinggian dari laut $700 \mathrm{~m}$ dan jarak ke ibukota kecamatan $9 \mathrm{~km}$, kabupaten $7 \mathrm{~km}$ dan propinsi $310 \mathrm{~km}$.

Penduduk Desa Sarira berjumlah 4451 jiwa, terdiri dari laki-laki 1.685 orang dan wanita 2.766 jiwa. Mereka terdiri dari $952 \mathrm{KK}$ yang menyebar pada 3 buah dusun (RW) dan 9 buah RT.

Dari jumlah penduduk tersebut di atas, 1.364 orang diantaranya yang memiliki pekerjaan tetap sebagai sumber kehidupan, dengan perincian petani 255 orang, pedagang 166 orang, Pegawai Negeri/ABRI 122 orang, pensiunan 121 orang, buruh 144 orang dan yang paling banyak adalah pekerja di bidang keterampilan dan jasa sebanyak 556 orang. 
Keadaan penduduk menurut pendidikan, adalah Tidak Sekolah 70 orang, Tidak Tamat SD 1.700 orang, Tama t SD 779 orang, Tamat SLTP 661 orang orang, Tamat SLTA 599 orang dan Akademi/Perguruan Tinggi 11 orang.

Sarana pendidikan yang ada terdiri dari SD 4 buah, SLTP 1 buah dan SLTA (SMU/SMK) 5 buah.

Keadaan penduduk menurut agama adalah : Islam 110 orang, Kristen 1.788 orang, Katholik 1.276 orang dan Hindu 3 orang. Selain dari itu adalah penganut Aluk Todolo sebanyak 1.274 orang.

Sarana ibadah terdiri dari : Masjid 1 buah dan gereja 22 buah. Di Sarira terdapat juga Puskesmas pembantu 1 buah. Organisasi keagamaan yang ada, yaitu Remaja masjid, PPGT dan PWGT, dan organisasi sosial adalah Karang Taruna.

\section{£. Pengumpulan Data}

Pengumpulan data dalam penelitian ini dilakukan dengan cara :

a. Pengamatan terlibat terhadap peristiwa yang terjadi selama penelitian dilakukan, situasi dan kondisi yang mempunyai makna dalam kehidupan ber agama masyarakat.

b. Wawancara mendalam dengan pemuka masyarakat, tokoh agama dan aparat desa;

c. Studi kepustakaan yang relevan dengan topik penelitian, di perpustakaan yang ada di Rantepao.

Pengumpulan data bersifat kualitatif, yang sasarannya adalah kenyataan empirik yang ada dalam masyarakat Toraja di Desa Sarira.

No. 15 Th.X Juli/Desember 1998

\section{ASPEK KEAGAMAAN \\ DALAM KEHIDUPAN SOSIAL MASYARAKAT.}

\section{Kepercayaan Aluk Todolo}

Aluk Todolo terdiri dari dua suku kata yang berarti : agama asli (orang Toraja).

Aluk Todolo adalah kepercayaan yang dianut etnis Toraja, Sulawesi Selatan, sejak dahulu kala dan dikategorikan sebagai kepercayaan animis. Istilah Aluk Todolo populer setelah masuknya agama lain di Toraja, Untuk membedakan keyakinan yang dianut semula dengan agama yang datang kemudian, seperti agama Islam, Kristen dan Katholik. Menurut kepercayaan Aluk Todolo, Tuhan yang paling tinggi ialah "Puang Matua", dialah pencipta manusia pertama dan alam dengan segala isinya. Puang Matua dikenal juga dengan "Totumampata". Untuk mengatur kehidupan manusia, Puang Matua menurunkan Aluk Todolo dengan segala persyaratan hukumnya. Hukum dimaksud disebut "Pemali", yang harus dipatuhi oleh para penganutnya, antara lain :

- Larangan berzina, pemali ma'pangan bumi

- Larangan mencuri : Pemali boko

- Larangan membunuh orang : Pemali umbako sunga'na padanta to lino

- Larangan berdusta : Pemali makada penduan

- Larangan mengganggu upacara kuburan : Pemali urrusak pate dibolong

- Larangan mengambil barang di kuburan : Pemali meloko

- Larangan berkhianat pada orang tua : Pemali unkasirisan deata misanta

- Larangan menyiksa hewan ternak : Pemali umbala'-bala' patoan.

Jumlah pemali menurut Aluk Todolo ada 100 yang disebut Aluk Sanda Saratu. Apabila penganut Aluk Todolo melakukan pelanggaran akan dikenakan hukum sebagai sanksi. Berat ringannya sanksi tergantung besar kecilnya pelanggaran yang dilakukannya. 


\section{UPACARA KEAGAMAAN ALUK TODOLO}

Upacara tradisional masyarakat, pada umumnya berkaitan erat bahkan ditandai dengan upacara keagamaan. Upacara-upacara yang dilakukan oleh Aluk Todolo pada dasarnya terbagi dua bagian, masingmasing : Alu Rambu Tuka atau Aluk Rampe Matallo dan Aluk Rambu Solo atau Aluk Rampe Matampu'

\section{Aluk Rambu Tuka}

Upacara Rambu Tuka disebut juga Aluk Rampe Maiallo, pelaksanaannya dipimpin oleh "Tominaa", meliputi upacara kelahiran, menaiki rumah baru, berkembang biaknya hewan ternak, berhasilnya perkebunan dan sesudah panen pertanian, sebagai tanda syukur atas keberhasilan usaha kehidupan dan keselamatan. Di samping itu, upacara dan memberi kehidupan dan keselamatan.

Hewan yang dikurbankan dalam upacara Rambu Tuka adalah ayam, babi atau kerbau.

"Kehidupan masyarakat Toraja sepanjang tahun terlibat dalam upacara keagamaan seperti pesta panen padi, pesta rumah adat dan upacara pemakaman orang mati " (A.T. Marampa' : 59).

Pemujaan dan persembahan Aluk Rambu Tuka, mempunyai tahapan sebagai berikut :

- Kapuran Pangngan : menyajikan "sirih pinang", sebagai tanda melaksanakan hajat dengan kurban persembahan.

- Peong Sanglampa : menyajikan persembahan dengan menghidangkan sebatang "lemang" (nasi ketan dalam bambu) di tempat pelaksanaan upacara.

- Ma'paling : persembahan kurban berupa ayam, sebagai penryataan kekurangan yang dimiliki manusia sehingga dapat terhindar dari kesalahan

- Ma'tadoran : persembahan kurban ayam atau babi untuk "deata" (dewa) yang menguasai tempat upacara.

\section{UPACARA RAMBU TUKA, antara lain :}

\section{a. Mangara' Banua:}

Membangun rumah adat yang disebut " Tongkonan" atas biaya bersama. Selesai tongkonan dibangun, sebelum ditempati, dihadiri seluruh keluarga dan masingmasing memotong babi. Dalam upacara ini diadakan juga tari-tarian (Magellu, Daobulan, dsb) sebagai tanda syukur.

\section{b. Ma'bugi:}

Upacara ini dilakukan sebagai tanda syukur setelah panen atau sesudah terjadi wabah penyakit agar tidak terulang lagi.. Yang datang dalam upacara ini memotong ayam, dan menanak nasi ketan dalam bambu (lemang) dan minumannya dengan tuak (nira). Sesajen tersebut dimakan bersama dalam upacara

c. Maro

Upacara "Maro" dilakukan untuk men yembuhkan orang sakit yang diganggu oleh makhluk atau roh halus. Dukun yang memimpin upacara akan kemasukan juga roh halus, dan bila si sakit sembuh maka dukunpun menjadi sadar setelah mengadakan kontak dengan deata (dewa). Dalam proses penyembuhan, dilakukan juga tarian "maro" disertai lagulagu "maro".

\section{d. Merok}

Upacara pemujaan dan persembahan kepada "Puang Matua" sebagai pemujaan tertinggi. Kurban per-sembahan adalah kerbau, babi dan ayam.

Acara "merok" berlangsung beberapa hari dan dilaksanakan antara lain untuk :

- Kelengkapan pesta upacara kematian bangsawan.

- Syukur besar pada saat keluarga mendapat kekayaan. 


\section{ASPEK KEAGAMAAN DALAM KEHIDUPAN SOSIAL MASYARAKAT TORAJA DI DESA SARIRA, RANTEPAO, TANATORAJA}

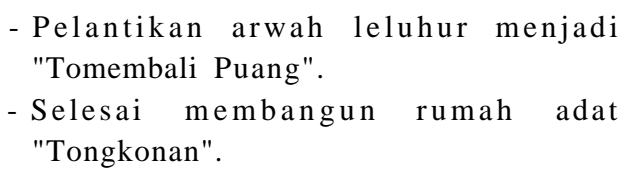
ALUK RAMBU SOLO

Aluk Rambu Solo disebut juga Rampe Matampu' adalah upacara pemakaman dan kematian yang terikat dengan kepercayaan Aluk Todolo. Menurut kepercayaan Aluk Todolo, bahwa orang mati itu hanya perubahan proses hidup, tetapi rohnya tetap hidup di alam gaib, maka tetap diperlakukan seperti orang hidup melalui upacara adat. Hewan yang dikurbankan, pakaian yang dikenakan kepada may at, dan seluruh peralatan dalam pelaksanaan upacara akan dibawa serta arwahnya ke dalam "puya" (duniajiwa).

Para keluarga dekat yang ditinggalkan si mayat, menjadi konsekwensi tanggungjawab solider bagi mereka, memenuhi persyaratan agama dan adat, dengan memberikan pengorbanan, dimana seluruh kehidupan masyarakat penganut Aluk Todolo diarahkan untuk upacara adat pemakaman, sesuai kedudukan dan status sosial dan kemampuan mereka.

- Tata cara pemakaman bagi penganut Aluk

Todolo, bertingkat-tingkat menjadi 4 golongan yaitu :

\section{Disilli}

"Disilli", upacara pemakaman yang paling sederhana dan berlaku di kalangan budak atau orang-orang miskin. Mayat dibungkus dan dibekali sebutir telur dan diantar ke kubur pada malam hari. Pada upacara pemakaman hanya memotong seekor babi. Upacara disilli berlaku juga bagi anak yang meninggal dunia dari segala lapisan masyarakat, sebelum gigi anak itu tumbrh.

2. Dipasambongi

Upacara "dipasambongi" berlangsung hanya semalam di rumah duka dengan mengurbankan hanya seekor kerbau dan 4 ekor babi, kemudian keesokan harinya diantar ke pemakaman atau ke liang.
Dipasambongi dilakukan bagi penganut Aluk Todolo golongan menengah tetapi tidak mempunyai kemampuan.

\section{Dibatang}

Upacara "dibatang" disebut juga "Didoya Tedong", yaitu upacara pemakaman yang dilakukan dengan memotong kerbau lebih dari satu ekor. Upacara ini berlangsung beberapa hari dan setiap hari dilakukan pemotongan kerbau.

Pelaksanaan upacara ini adalah sebagai berikut :

\section{a. Dipatallungbongi}

Upacara yang dilaksanakan selama 3 hari 3 malam dengan memotong kerbau 1 ekor sehari ditambah babi seadanya. Untuk pelaksanaan upacara dipatallungbongi, di halaman tongkonan dibangun pondok-pondok untuk ditempati seluruh kerluarga selama berlangsungnya upacara.

\section{b. DiPalimangbongi}

Upacara diselenggarakan selama 5 hari 5 malam, di sekitar tongkonan. Kerbau yang dipotong 1 atau 2 ekor tiap hari dan babi beberapa ekor. Kenalan dan sahabat si mayat yang datang mengikuti upacara, membawa sumbangan berupa tuak, buah-buahan, rokok, gula pasir, dan sebagainya. Pada malam terakhir diadakan acara khusus yang disebut "ma'parando", dimana semua gadis yang menjadi cucu si mayat diarak dimalam hari keliling rumah tiga kali putaran dengan memakai obor.

\section{c. Dipitungbongi}

Upacara dilakukan selama 7 hari 7 malam, setiap hari ada pemotongan kerbau, kadang sampai 20 ekor, dan babi tidak terikat jumlahnya. Daging hewan sembelian dibagi-bagi kepada tamu dan masyarakat, tatapi kepala kerbau diperuntukkan bagi Tongkonan. 


\section{ASPEK KEAGAMAAN DALAM KEHIDUPAN SOSIAL MASYARAKAT TORAJA \\ DI DESA SARIRA, RANTEPAO, TANATORAJA}

Setiap pelaksanaan upacara kematian tersebut di atas, setiap malam dilakukan acara "Ma'badong", melalui "kata-kata badong" yang diucapkan dengan nada sendu oleh keluarga dan tamu yang berkenan. Isi ma'badong adalah mengungkap kembali riwayat manusia sejak dalam kandungan ibu, dilahirkan, kehidupannya dalam masyarakat sampai meninggal dunia dan seterusnya menuju alam "puya".

\section{Dirapai}

Penguburan orang mati bagi masyarakat Toraja adalah upacara yang paling sakral dan menelan biaya amat banyak serta menggunakan waktu yang sangat lama. Proses acara kematian disebut "dirapai"' atau "mengrapai"', dimana sebelum dikubur, terhadap orang mati dilakukan :

-Ma'dio tomate, yaitu dimandikan kemudian dikenakan pakaian kebesarannya bersama perhiasan yang dimilikinya.

- Mangremba' atau ma'doya, dengan memukul seekor ayam sebagai tanda bahwa yang bersangkutan resmi dinamakan orang mati (tomate).

- Ma'balun, mengafani mayat menurut adat Toraja.

- Ma'balong, pernyataan seluruh keluarga berkabung

Upacara ini biasanya dilakukan di rumah adat (tongkonan).

- Ma'palao

Orang mati dipikul ratusan orang dan diarak dari rumah tongkonan ke tempat upacara penguburan yang disebut "rante". Dalam rante ini dibangun rumah tinggi tempat orang mati disemayamkan selama upacara berlansung, yang disebut "Lakkian". Acara yang dilakukan sebagai rangkaian upacara di rante adalah adu kerbau, tari tarian dan sisemba' (adu kekuatan betis).
Selama upacara berlangsung, sejumlah hewan dipotong berupa kerbau puluhan ekor dan babi ratusan ekor, menurut status sosial dan kemampuan ekonomi keluarga orang mati.

Orang mati menurut Aluk Todolo tidak dikuburkan di dalam tanah, tetapi dimasukkan ke dalam goa yang ada di lereng-lereng bukit yang tinggi dan terjal. Makin sulit dijangkau manusia makin baik dan makin aman. Bagi bangsawan atau orang kaya, sengaja dibuatkan lubang di tempat ketinggian "Liang", ke dalam liang itulah orang mati dimasukkan sebagai tempat penguburan.

\section{Tomcmbali Puang}

Penutupan upacara orang mati dinamakan "Pembalikan Tomate" yaitu upacara membersihkan jiwanya agar berhak diterima di depan Puang Matua. Upacara ini disebut "Tomembali Puang"

Aluk Todolo percaya bahwa arwah orang mati akan menuju ke suatu tempat peristirahatan. Roh yang keluar dari jasad, akan memasuki kehidupan baru di alam lain yang disebut "puya", yang dikuasai oleh "Ponglalondonga" dewa yang mendapat kekuasaan mengatur kehidupan arwah dari Puang Matua.

Upacara kematian sebagai upacara keagamaan adalah puncak dari segala kegiatan sosial kemasyarakatan bagi penganut Aluk Todolo di Tana Toraja, sehingga dalam upacara tersebut, baru nampak status sosial dan status ekonomi dari suatu keluarga.

Upacara adat yang berkaitan dengan daur hidup lainnya seperti; perkawinan, kelahiran, pendirian rumah, acara tanam padi dan waktu panen, dilakukan dalam bentuk sederhana, walau masih terkait dengan ritual Aluk Todolo, dan persembahan yang disajikan tetap menjadi perhatian masyarakat. 


\section{ASPEK KEAGAMAAN DALAM KEHIDUPAN SOSIAL MASYARAKAT TORAJA \\ DI DESA SARIRA, RANTEPAO, TANATORAJA}

\section{KESIMPULAN}

Suku Tonvja adalah salah satu etnis di Sulawesi Selatan yang masih kuat mempertahankan tradisi yang merupakan budaya turuntemurun dari leluhur mereka. Kepercayaan masyarakat adalah "Aluk Todolo" dianut sebagai agama dimana "Puang Matua" dianggap pencipta manusia dan alam dengan segala isinya.

Upacara keagamaan Aluk Todolo terbagi dua macam : Pertama, "Aluk Rambu Tuka" meliputi upacara kelahiran, menaiki rumah baru, tanda syukur atas berkembangbiaknya ternak, berhasilnya kebun dan sesudah panen. Kedua, "Aluk Rambu Solo", upacara yang menyangkut kematian dan upacara penguburan.

Pemujaan dan persembahan dalam pelaksanaan setiap upacara, ditandai dengan kurban berupa kerbau, babi dan ayam. Jumlah hewan yang dikurbankan bervariasi menurut jenis upacara dan tergantung kemampuan kaluarga. Khusus upacara penguburan, yang menelan biaya amat besar karena penyembahan kadang sampai puluhan kerbau, ratusan babi dan ayam, dan membutuhkan waktu yang lama, sering bulanan, bahkan antara kematian dan penguburan biasa membutuhkan tenggang waktu 1 - 3 tahun.

Pemali adalah larangan bagi penganut Aluk Todolo, dan pelanggaran pemali, pelakunya akan mendapat sanksi. Berat ringannya sanksi tersebut tergantung jenis pelanggaran yang dilakukan.

Upacara keagamaan yang berkaitan dengan kehidupan sosial masyarakat Toraja, disamping sebagai perwujudan pengabdian dan penyemba'ran kepada Tuhan, juga menjadi obyek wisata yang banyak menarik wisatawan baik Domestik maupun wisatawan Manca Negara, bahkan menjadi bagian dari budaya bangsa Indonesia.

\section{KEPUSTAKAAN}

Depdikbud Upacara Tradisional Daerah Sulawesi Selatan, Depdikbud Wilayah Sulsel, Ujungpandang, 1981/1982.

Koentjaraningrat Aspek Manusia Dalam Penelitian Masyarakat, Gramedia, Jakarta, 1985.

Marampa', AT, Mengenal Toraja

Mukti Ali Pee Indonesia, Sinar Harapan,Jakarta, 1982.

Parsudi Suparlan, Pengetahuan Budaya, Ilmu-Ilmu Sosial dan Pangkajian Masalah-Masalah Agama, Balitbang Agama, Jakarta 1981/1982.

Salombe C, Orang Toraja Dengan Ritusnya, In Memorian So' Rinding Puang Sangalla, Ujungpandang, 1972.

Sy. Moh. Fuad,Islam di Tana Toraja, Posisi Sosial Religius Dari Persekutuan Masyarakat Muslim Madandan di Tana Toraja, PLPIIS Unhas, Ujungpandang, 1985. 